\author{
Bazmohammad Forogh (iD, Shirali Samimi* \\ Bamiyan University, Afghanistan, Bamiyan \\ * e-mail: a.alisamimi.s7@gmail.com
}

\title{
ABUL-FAZL GOVERNANCE AND ADMINISTRATION DURING THE REIGN OF JALAL-UD-DIN MOHAMMAD AKBAR
}

\begin{abstract}
Abul-Fazl was the best friend and vizier of Jalal-ud-din Mohammad Akbar the third king of Moghul dynasty in India from (1556 - 1605), he is the author of famous book well known the Akbarnama, that was the official history of Akbar's reign in three volumes, also he is author of another book the Ain-i- Akbari and a Persian translation of the Bible. He was also the brother of Faizi, the poet laureate of Emperor Akbar. In this article we will know how the emperor of Mughal dynasty who originally went from Afghanistan to north India and built a huge empire beginning in 1526 by grandfather of Akbar Zahirudding Mohammad Babur, it lasted more than two centuries. The Mughal become one of the most important dynasties of the subcontinent. The splendor and luxury of the courts, the policies of the emperors and the system of administration and taxation that the Mughals established have had a deep impact. Akbar widely considered the greatest of the Mughal emperors, was only 14 years old when he ascended the throne in Delhi, following the death of his father Humayun.
\end{abstract}

Key words: Akbar, imperial court, emperor, subcontinent and Mughal dynasty.

\author{
БазмохаммаА Форог, Ширали Самими* \\ Бамиян университеті, Ауғанстан, Бамиян к. \\ *e-mail: a.alisamimi.s7@gmail.com \\ Жалал-УА-Аин Мохаммад Акбар кезеңіндегі \\ әкімшікік және Абул-Фазмдің басқаруы
}

Абул-Фазл басқарушы Ажалал-аА-дин Мұхаммед Ақбардың ең жақын досы және уәзірі болды. О^ Үндістандағы Моғолдар әулетінің үшінші патшасы (1556-1605 жж.), әрі ол әлемге әйгілі «Ақбар нама» кітабының авторы. Билеуші Абул-Фазл Ажалал-ал-дин Мұхаммед Ақбардың билігі жайлы үш томдық кітабын жазған, сонымен қатар Айн-и-Акбаридің тағы бір кітабының авторы және Інжілдің парсы тіліндегі аудармасын жасаған. О^ сонымен бірге Император Ақбардың ізбасары Файзилің ағасы ретінде белгілі. Мақалада біз 1526 жылы Ақбар Захирудлиннің атасы Мұхаммед Бабыр бастап Ауғанстан мемлекетінен Үндістанның солтүстік бөлігіне көшіп, қалай үлкен империя құрғанын және Моғол әулетінің императоры екі ғасырдан астам өмір сүргенін білеміз. Моғолдар Шығыс жері субконтиненттегі маңызды әулеттерінің бірі болды. Билеушілік, әкімшілік қызметін атқаруына сол кездегі соттардың сәні мен салтанаты, императорлардың саясаты, Моғолстан мемлекеті құрған әкімшілік пен салық жүйесі үлкен әсер етті. Абул-Фазл билеуші ретінде Ажалал-аА-дин Мұхаммед Ақбарды Моңғол императорларының ең үлкені деп санайды. О^ әкесі Хумаюн қайтыс болғаннан кейін Аелиде әкесінің орнына таққа отырған кезде небәрі 14 жастағы жас бала болатын.

Түйін сөздер: Акбар, империялық сарай, император, субконтинент және Моғол әулеті.

\author{
Базмохаммад Форог, Ширали Самими* \\ Бамианский университет, Афганистан, г. Бамиан, \\ *e-mail: a.alisamimi.s7@gmail.com \\ Управление Абул-Фазм и аАминистрация \\ во время царствования Ажалал-УА-Аин МохаммаА Акбар
}

Абул-Фазл был мучшим другом и визирем Ажалал-уА-дина Мохаммада Акбара, третьего короля Аинастии Моголов в Индии (1556-1605 гг.), он яв^яется автором известной в мире книги Акбар нама, которая была официальной историей правления Акбара в трех томах. Также он является автором другой книги Айн-и-Акбари и персидского перевода Библии. Он также бы^ братом Файзи, поэта и кауреата императора Акбара. В этой статье мы узнаем, как император Аинастии Великих Моголов, который первоначально отправился из Государства Афганистана в северную Индию и построи^ там огромную империю, начатую в 1526 году дедом Акбара 
Захируддинга Мохаммедом Бабуром. Она просуществовала в истории более двух столетий. Моголы стали одной из самых важных династий субконтинента Востока. Великолепие и роскошь судов, политика императоров, а также система аАминистрирования и налогообложения, установленная династии Моголами, оказали глубокое влияние. Акбар считается величайшим из императоров Великих Моголов. Ему было всего 14 лет, когАа он взошел на трон в Аели после смерти своего отца Хумаюна.

Кмючевые слова: Акбар, императорский Авор, император, субконтинент и династия Великих Моголов.

\section{Introduction}

Among the Muslim elite, history was considered as the third important source of knowledge after the religious scripture and jurisprudence. Therefore, the study and writing of history were accorded great importance after the establishment of the Delhi Sultanate in the closing years of $12^{\text {th }}$ century. The pioneers of history-writing in the Indo-Persian tradition was Muhammad bin Mansur, popularly known as Fakhr-i Moudaber. His writings included a book of genealogies of the Prophet of Islam and the Muslim rulers, including Qutbuddin Aibak.

Minhaj Siraj Juzjani was another important historian of the $13^{\text {th }}$ century. However, the most important figure in the Indo-Persian historiography was Ziauddin Barani in the $14^{\text {th }}$ century. His Tarikh- $i$ Firuzshahi is a milestone in the tradition of historywriting in medieval India. It was written for the enlightenment of the rulers of his times. Under the Mughals this tradition of history-writing continued and reached new heights. Abul Fazl, Nizamuddin Ahmad, Abdul Qadir Badauni, Khwaja Kamgar Husaini and Abdul Hamid Lahori were some important historians of the Mughal period, as I mentioned before, Medieval India had many eminent historians and among them Shaikh Abul Fazl (15511602) occupies a place of distinction. Thus is mainly because of the predominance of intellectual elements in his writings, his unfailing appeal to reason against religious and cultural traditions, broader view of history and a new methodology which he sought to apply to his task. His interpretation of history was integrally linked to the political, social, economic and religious realities of that period.

At the beginning of the Mughal period, India was divided into many smaller kingdoms, and this frequently led to a great deal of political instability. This ended with the victory of the Mughal ruler Babur over Ibrahim Lodi, the last ruler of the Delhi Sultanate. The Mughals eventually conquered much of India resulting in an integrated and vast Mughal Empire, which had many new characteristics. It had a hierarchical administrative structure, strong monetary policies, centralized governing system and new methods of military organization, and there was an emergence of fresh ideas in the cultural and religious fields. These new structures gave rise to a novel integrated culture that had elements from both Hindu and Muslim thoughts, an idea that found a clear expression in the tradition of the Bhakti and Sufi movements. The primary message was that no religious is inferior to any other, God can be found without blind belief in superstations, that all humans are equal and that there is a basic unity and equality in all religions.

Political Ideas in Islam have various sources. A part of it can be traced to pre-Islamic sources and a substantial part was based on the teaching of the Prophet Mohammad. The concept of one God and the universality of laws of the Quran fostered the doctrine of equality, which forms the basis of Islamic brotherhood. Politically however the Islamic belief was that, some are born to rule and others to obey, an idea that was closer to the Greek belief of superior and inferior. Abul Fazl, a contemporary of Abdul Qadir Badayuni, was a courtier historian and also a friend to Akbar, the greatest of all Mughal rulers. He finished his massive and definitive work, the Akbar Nama and Ain-i-Akbari, in the waning years of the $16^{\text {th }}$ century, it marks a decisive and schematic departure from the predominant historiography format of the time as it does in several other aspects of the construction of an alternative world view. The Akbar Nama opens with the praise of Allah, for sure and then moves to Adam and traces Akbar's lineage back to fifty three generations of his ancestors, it dislocates the historiographic axis from the groove of Islam and seeks to construct on alternative teleology of universal history in which Akbar is the heir not of Mohammad and caliphs, but of Adam himself, the first human being and thus the ruler of humanity. The text therefore promotes the idea of a powerful sovereign and a centralized state structure.

Akbar Nama and the Ain-i-Akbari together constitute a single book, the first part of the Akbarnama contains in account of Akbar's ancestors, including that of his father Humayun. The second 
part gives the most complete account of Akbar's reign up to the $46^{\text {th }}$ year, in a chronological order. The work was undertaken in 1595 and after five revisions, completed in 1602. The Ain-i-Akbari is the third parts of the book, it is a unique compilation of the system of administration and control over the various department of government in a great empire. If faithfully and minutely records to the minutes details, a wide array of facts, illustrating its extent resources, condition, population, industry and wealth as the abundant material supplied from official sources could furnish. It also contains on account of the religious and philosophical system of the Hindus as described in their ancient books, and of their social customs and practices. Thus Abul Fazl widened the range and scope of history as no medieval historian before him had done and his work is considered the most comprehensive account of Mughal administration and state structure.

\section{Materials and methods}

Abul Fazl had a rational and secular approach to history, he also applied a new methodology to collect facts and marshal them on the basis of critical investigation. These are the hallmark of his writing. He widened the scope of history by recording a mass of facts pertaining to political, social, economic, and cultural life and by incorporating chapters on administrative regulation procedures and topographical accounts of various provinces. He laboured hard for the collection of material, selected imperial facts after careful enquiry and investigation and then presented them in a clear and systematic manner; he questioned the validity of sources and accepted it only when it satisfied the principles of historical investigation formulated by him. In other words he created a new idiom for understanding and interpreting history. Widened its range and scope and laid down the principles of historical investigation. It may therefore be suggested that in Abul Fazl's writings we can discover a philosophy of history.i.e. A definite concept about the nature and purpose of history. Principles for its interpretation and the critical approach for the collection and selection of facts of history (Hassan, 1983:130).

Abul Fazl realized and recognized the importance of original sources and gave his utmost attention and care to its study. He did not depend on a single source or account in order to assertion a fact, but obtained as many versions as he could. They were put to a: critical examination before they were accepted, he starts that he has formulated a set of question which were out to the reporter of an event or fact. These procedures, he points out is of great help to the historian in ascertaining the truth, his source material consisted of accounts of events written by eye witness. Reports, memoranda, minutes prepared by the offices, imperial Farmans and other records were carefully consulted (Abul Fazl, 1989: 367).

In the political field, Abul Fazl can be compared with Barani of Delhi Sultanate, while both of them were concerned with social stability, Abul Fazl's methods of handling this concept was different, Aini-Akbari create a theory of sovereignty promised on social contract. He drew a picture of society that existed before and then explained how sovereignty emerged (Ali, 2006: 125).

\section{Results and discussion}

\section{Divine theory of Padshah and the concept of royalty}

According to Abul Fazl the term Padshah meant 'an established owner' where Pad stands for stability and Shah stands for owner. Padshah therefore means powerful, established owner who cannot be eliminated by anyone (Abul Fazl, 1989: 367). The Padshah had a superior place in the Mughal Empire, he was the ultimate authority on all social, economic, political and judicial powers. This theory of Padshahat was a combination of Mongol, Turkish, Iranian, Islamic and Indian political traditions. According to Abul Fazl 'Badshahat is the light derived from God which has been sent by God himself, God throws his kindness on Badshah who works as the agent of God (Ali, 2006: 126). A Badshah considered himself as the father and his subjects were his children, so it was his duty to make every efforts for the welfare of his people and take care of every aspect of their life, be it economic, social, political, and religious and so on. He should always treat his people equally to maintain peace and harmony in his empire (Abul Fazl, 1989: 255).

It is evident in the writing of Abul Fazl that Akbar was interested in establishing the authority of the Badshah over all other elements of the state. In 1579, through a decree named Mazhar, Akbar gained a great deal of authority to interpret law, but he was not satisfied with this limited power. This remained controversial as he was compared with the great Muslim jurists like Imam Abu Hanifa, Hamble and others. Akbar after some time lost interest in the position of kings of Islam. He wanted a wider concept of religion. He sought for a new justification of religious thoughts and Abul Fazl provided this to him. Abul Fazl told him the new meaning 
of sovereignty as a divine light, later on Akbar portrayed himself as an agent of God who worked in his behalf, According to Abul Fazl, sovereignty was in nature, a divine light "farr-i-Izadi" and with this statement he seems to dismiss as inadequate the traditional reference to the king as the shadow of God "zill-i-Ilahi” (Ali, 2006: 125).

\section{Sovereignty in Badshahat}

The king established his sovereignty by considering himself an agent of God and used his absolute powers according to the rule of the controller, guide and state Abul Fazl considered Badshah as the father of his people so it was the duty of people to respect him and obey his orders. But if the Badshah discriminated on the basis of caste, religion and class then he could not be considered a good king. According to him the king had been given miraculous power, it was impossible to challenge him and nobody could share his power, during the Delhi Sultanate the king was the final authority in governance, administration, agriculture, education and in other fields, but he had no say if they were related to religious matters, but when Akbar acquired kingship he made himself the final authority even in religious disputes vis-a-vis the Imam-e-Adel, because he followed the order of God and he could not be wrong. Therefore people must follow his order, it is clear that Akbar was the ideal king for Abul Fazl and that's why he looked at Akbar as a complete man who could never be wrong (Yadav and Sharma, 2000: 338-39).

\section{The Imperial Court}

The Mughal Empire was a Muslim Personate imperial power of the Indian subcontinent which began in 1526, ruled most of the Indian Subcontinent as Hindustan by the late 17th and early 18 th centuries, and ended in the mid-19th century. The Mughal Emperors were descendants of the Timurid, and at the height of their power, around 1700, they controlled most of the Indian Subcontinent - extending from present-day Bangladesh in the east to Baluchistan in the west, Kashmir in the north to the Kaveri basin in the south. Its population at that time has been estimated at between 110 and 130 million, over a territory of over 4 million $\mathrm{km}^{2}$. Following 1725 it declined rapidly, weakened by wars of succession, agrarian crises fueling local revolts, the growth of religious intolerance, and British colonialism. The last Emperor, Bahadur Zafar Shah II, whose rule was restricted to the city of Delhi, was imprisoned and exiled by the British after the Indian Rebellion of 1857. Akbar had in place a policy of incorporating his opponents into his imperial administration by treating them generously and providing them with lives much better than their previous ones as autonomous warriors. He would offer new opportunities for imperial service to many of the defeated nobles, their kinsmen, and most other preexisting state positions. (Richard, 2002:10)

The newly incorporated officials would become Zamindars (local level land-holders), and some would even be promoted to high-ranking Mansabdars (imperial rank holders). The system of Akbar's Hindu Mansabdars was starting from (haft hazari the higher rank that guided seven thousand soldier and the lower was to Do Sadi. The Mansabdari system of Mughal was the basis of civil and military administration of the country, the system was introduced by Akbar who borrowed it from Persia. It differed fundamentally from the feudal system of Europe in the sense that it had nothing to do with land and was also not hereditary. The Mansabdari system provided the Mughals with a civil service. (Mahajan, 1997:105)

At the time Akbar ascended the throne as ruler of the Mughal Empire, he inherited a land revenue system that did not have great influence upon the local economy. He did, however, understand the abilities of the land revenue system begun by prior Indo- Muslim regimes, such as the ruler Sher Shah Sur. Rather than try to create a new revenue system; Akbar employed the help of his advisers to reform this one. (Malleson, 1899: 185) Akbar's fiscal reforms had the administrative purpose of stabilizing the village-level peasant population while consolidating regional rule directly under his command. It was imperative that Akbar create a land revenue system and administration that gave the appearance of a cohesive central government in order for all of his subjects to unquestionably view Akbar and the Mughals as legitimate rulers. Here, Akbar's policies show how important Akbar considered support from all classes of the population - not just from the ruling class - in order to legitimize his rule within the empire. The reformations of the land revenue system included reorganizing all of the Mughals' land and correcting the inherent corruption of the system. Akbar began by reclassifying all land holdings into five categories based on the fertility of the soil. Under the new regulation land tax system, imperial revenue officials, theoretically, gathered reports on the status of the cultivation of each peasant in each village. From the reports, they assessed taxes based on the recorded prices and yields specific to each locality. In 1580, Akbar and his advisers succeeded in the reorganization of the empire on the provincial level of the tax revenue 
system with the establishment of twelve provinces (Streusand, 1989:113).

Each province, by imperial decree, was to have its own administration, consisting of seven posts who were both functionaries of the province and people who reported to the central administration, as well. The governors had military control over the region, but not administrative free reign. Through this division between civil and military authority, Akbar had begun to restrict the autonomy of the provincial governors. Another reform, one which shocked the upper rung of the Muslim hierarchy, was the re-examination of all religious land grants. Akbar analyzed each grant and reassessed them personally. For these reexaminations, Akbar arranged private interviews with the Shaikhs and Ulemas (leaders of Sufi brotherhoods and scholars) to decide whether each land grant was valid. He upheld the validity of many land grants if he was satisfied, but those religious leaders who had disciples, held spiritual soirees, or claimed to have accomplished miracles were punished by a withdrawal of their grants (Habib, 1997:75).

The reassessment of all land grants shows that Akbar wanted to establish from the beginning of his rule the idea that he kept close watch over the religious Muslim authorities, the Shaikhs and Ulema. Akbar's control of the Muslim officials demonstrates the sultan's commitment to establishing Mughal legitimacy in Hindustan and to separating himself from the corrupt, dysfunctional elements of a Muslim-run empire. The greatest improvement to the administration and land revenue system was the development of the Mansabdari system, which created a hierarchy of officials, all of whom were exclusively loyal to the sultan. This new system for administration was meritocratic and not based on a religious aristocracy. Previously, the Muslims in India formed the governing class from which all high officials were drawn. However, Akbar ended Muslim superiority in his empire by choosing men on merit, rather than on the basis of kinship, religion, or nepotism, including many very able non-Muslims. The inclusion of Hindus into high posts of the administration was a form of tokenism.

Their elevated stature would allow other Hindus who came to court to recognize Akbar's superiority, as Hindus would already be standing near him. It also expressed to every person that the Mughal Empire was not subject to a harsh, fundamentalist Muslim rule, but was subject to the goal of the equality of all of its subjects. The hierarchal system of imperial rank existed in Akbar's Mughal lineage, but he viewed it as inefficient for his ideal administration. Babur was the first to bring this Mongol system to the Indian subcontinent. With the exception of the numerical rank, his system had a division between high officials, labeled "great Begs", and lower officials, "Begs." All of Babur's officials were members of a regular service, which had formal appointments and promotions, as well. Mirroring the formality of the regular service system before him, Akbar's Mansabdari system also sought to distinguish levels between rank holders. Akbar differed from Babur's system, however, as he was the first of his Mughal lineage to create the dual status of a separate civil and military rank for each rank holder.

Those who are experienced in this business have related wonderful stories of the purity of gold at the present time, and referred it to witchcraft and alchemy; for they maintain, that gold ore does not come up to this fineness. But by the attention of his Majesty, it has come up to this degree; hence the astonishment of people acquainted with this branch. It is, however, certain, that gold cannot be made finer, and of a higher degree. Honest describers and truthful travelers have indeed never mentioned this degree; but, when gold is put into fusion, small particles separate from it, and mix with the ashes, which ignorant men look upon as useless dross, whilst the skillful recover the metal from it. Although malleable gold ore be calcite and reduced to ashes, yet by a certain operation, it is brought back to its original state; but a part of it is lost. Through the wisdom of his Majesty, the real circumstances connected with this loss, were brought to light, and the fraudulent practices of the workmen thus put to the test (Bashir, 2009: 21).

\section{Toleration and Sulh-i-Kul-Doctrine of Peace}

The agent of God could not practice discrimination among the various faiths present in the society. A doctrine for justifying the tolerant religious policy was now the need of the hour, sovereignty was not restricted to any particular faith, it became overarching, and they believed all religions were in essence the same but only his paths varied. Abul Fazl carried this logical thought to Islam and Shariat, he could not find any justification for their sovereignty over others while Barani did so (Ali, 2006: 126). He believed that in a poly-religious country like India the theory of monarchical sovereignty was more relevant. Here sovereignty was not to be related with any particular religion as the monarch was above all the religious. He promoted the good values of different religions and thus assembled different faiths for maintaining peace everywhere, he had to sustain those qualities by adopting an appropriate religious status. $\mathrm{He}$ 
provided relief to himself and his people by giving them freedom from bound thoughts, after evaluating Abul Fazl, we can conclude that a sovereign must have the quality of tolerance for the existing beliefs and he should not reject the traditional ways of his people which necessary and complementary. Abul Fazl justified the views of Akbar by promoting him as having a rationalist approach to social reforms. Abul Fazl argued that he did so as he wanted to construct a Hindustan that could stand out in the world with greater confidence.

Division of Society

Abul Fazl gave the concept of sovereignty and state in the context of the needs of the society, on that basis he classified human into four categories as the warriors, artificers and merchants, the learned (religious class viz, Brahmans, Ulama), the husband men and labours. He put the learned class in the third place, he downgraded this class on the basis of the existing social reality of his time, he also classified human beings into three classes on the basis of Greek tradition, based on their qualities as noble, base and intermediate nobles were those who had pure intellect, sagacity, capacity of administration or composition of eloquence and personal courage for military duty, the base and intermediate sections included various professions, these were the qualities of the those who were self-centred and did their activities more for themselves than for and other (Chandra, 2007: 133).

According to Satish Chandra, Abul Fazl's view about human being particularly the lower classes called the base or the ignorable reflected in large measures the prejudices of the contemporary upper classes. It was implied that the lower orders should not aspire for a share in state power and that the task of administrating the state should be the preserve of those belonging to noble families and to upper castes. Prevalence of evil sections in society was a justification for royal despotism, for only a king who possessed the necessary qualities could control these sections. Secondly it was necessary for a king endowed with farr-i-Izadi to establish social stability by not permitting the dust of sectarian strife to arise, it was also obligatory for him to put each of these 'sections' in its proper place and by uniting their personal ability with due respect for others to cause the world to flourish. Thus stability even dignity implied the maintenance of one's due station in life. Akbar is quoted as saying that the Daroghah should be watchful to see that no one from covetousness abandons his own profession, elsewhere we are told that Akbar quoted with approval Shah Tahmasp's statement that, when a menial takes to learning he does so as at expanse of his duties.

The divinity of sovereignty clearly defied any restraints on the power and authority of the sovereign, of his several classification of human beings in different context, Abul Fazl divided one of them into three groups: the noblest souls are those, whose loyalty to the king. Akbar is absolute, unquestioning and undemanding, a virtue in itself. Placed below them are ones whose display of loyalty is on par with tangible gain, those who have made traffic of their services. The worst never shows any sign of loyalty. Rebellion, rebelliousness and their synonyms are the most damning language of abuse in medieval court literature; defending rebels became a cleansing operation, for Abul Fazl the rebellious were not merely the ones who defied imperial authority, even those like Rana Sangram Singh and Mahmud in Bihar, who refused to surrender to Mughal conquering power, were rebels, they defied the divine destiny manifested in history's teleology (Mukhia, 2005:50).

\section{Akbar as an ideal king}

Abul Fazl mentioned in Akbar Nama that Akbar always worked wisely for the welfare of his people. He had tolerance, broad mindedness had a strong sense of justice, he provided stability to the state and gave good governance to ensure economic prosperity, peace and safety of his people, and he provided religious freedom to all. His political views were clear and were intended for the expansion of the state boundaries. Therefore, Abul Fazl justified his policy of imperialism on moral grounds) Hassan, 1983: 133).

According to Harbans Mukhia, Abul Fazl envisions the sovereign essentially as paterfamilias, and bestows absolute power to them. Everything that the rulers dose, all gifts Mansabs or rewards bestowed by him upon his nobles, prices or subjects are favours, nothing is gained by anyone as a matter of right, on the other hand Abul Fazl's binds the rulers with bestowing paternal care to his subjects. Subjects are entrusted to the king by God, seems to be Abul Fazl's favourite phrase for the king as also the metaphors of shepherd, gardener and physician. The king as father motive is of course almost universal and has been prevalent across regions and civilization since ancient times, it is seen in almost all cultures and streams of thought from Buddhist to Greeco-Roman, ancient Egyptian, Assyrian and biblical. Enumeration of the request qualities of a ruler has understandably been of central concern to medieval political thought. For Zia Barani, a strong determination to conquer and 
govern nearly exhausted these qualities. For Babur good governance implied that the town walls be solid, subjects be thriving, provisions be in store and the treasury be full, but the running thread in Abul Fazl's several discussion of kingship is the composition of a paternal love towards his subjects, the priceless jewel of justice and fair play and observance of absolute peace. Sulh-i-Kul. Without discrimination, other traditions very with the context, at times out of step with one another, there is a grander vision to Abul Fazl's conception of sovereignty than enumeration a king's qualities, the true king must understand the "spirit of the age" (Mukhia, 2005:54).

\section{Justice}

It was also the duty of the king to provide justice to his people and always punish the wrongdoers and ensure that justice helped innocent people (Abul Fazl, 1989:774). According to him a king should be kind and harmonious while dispensing justice and treat his people as his children and himself as their father, he should keep it in his mind that he was sent by God on earth to ensure peace and justice for all. He is a medium for their welfare, his decisions should be transparent and he should always try to make his reign a civilized society, he should take the care of the basic needs of people, the king should try to place himself in the criminal's shoes at the time of judgement, he should consider every aspect of these circumstances in which crime had occurred and give his decisions only after that. If the king wanted to increase goodness of his state he should always give rewards to good people and punish the wrongdoers to inspire them to do good work (Appodoroy, 2002: 180).

Abul Fazl's basic premise was that the ruler should not depend on any religious person, his moral level should be high and should know the moral and spiritual qualities. He tried to show this concept of state and sovereignty in terms of Iranian traditions, according to him in a poly-religious state the concept of justice for all should be free from any bias irrespective of birth. He favoured abolition of Jizya, he convinced us that Akbar's conquest were not based on spiritual or religious difference, but they were necessary for justice as Indian politics was based on justice and tolerance and he called it Dar-ul-Sulh (Chandra, 2007: 134).

\section{Abul Fazl's views on Administration}

Humayun did not have time to revise the old administration, it was Akbar who revised it and gave it a structure of government and administration based on his knowledge of the Delhi Sultanate, and he did not make any change in administration at the district and sub district levels. His land revenue system was almost the same (Ali, 2006: 62). An important question arises here as to what was different or now that made the Mughal Empire stronger than the Delhi Sultanate? What were those new policies by which Akbar could govern such a large stable, long-lasting political and administrative structure? (Chandra, 2007:135).

As we know a strong and well planned administrative structure is a sound link of great governance, it is also necessary for welfare and peace of the state that people should not fear on enemy attack. All this could not have been possible in Akbar's empire if intelligent and loyal officers and army were not present, as the state could defeat the enemy with their help only. In reality Mughal polity was not a complete continuation of the Delhi Sultanate. He changed the designation of the officials, his important contribution was the development of a provincial administration, patterned on the central system of government, detailed rules and regulation were made for better control. In his administrative views Abul Fazl gave supreme place to advocates among all the officers, according to him advocates should have those qualities which could solve both private and social problems of the king (Mukhia, 2005:149).

As we see in Koutilya's Arthashashtra, the state was divided into many levels and each levels had many officers of various kinds, all of them were responsible for the administration of the state and answerable to the rulers directly and hence they always worked for the betterment of the public, we can find the same concept in the Ain-i-Akbari.

Akbar divided his empire into Subas, Sarkars and Mahals. He appointed a chain of officers of the various levels who were controlled by ministers at the centre, in this system the religious of the officers could not interfere in their administrative work, so this system was also followed by his successors. Akbar wanted a sovereign rule, so he gave importance to it, he systematized and centralized his administration. There were small landlords under the king who were known as Zamindars or Jagirdars, the king often used their forces to curb other chieftains (landlords). There was also a class called Bhumiya which got same land from the jagirdars. The Bhumia were the owners of the lands and did not have to pay duty for it but this land was always inferior to that of the Jagirdari land, there is also existed a Khalsa land which was under the direct control of the king, this land would be mostly in the vicinity of the capital, this system had flourished even during the Sultanate and the Mughals did not disturb it as the landlords 
kept the lands with those who were allied with the king of Delhi (Mehta, 1996:149). The Mughal state had a vast centralized patrimonial system in this system they bestowed various kinds of ranks and hierarchies borrowed from the Mansabdari system of Persia (in Persian Mansab means rank). These ranks had two parts comprising Zat and sawar, each Mansabdari had some rights (zat) and a force of horses to command (sawar).

The ruler provided him the grant of his strength, the Ain-i-Akbari mentions sixty six ranks, at that time the system granted gifts to the deserving, all the Mansabdari reported directly to the ruler, they also collected revenue on the behalf of the king and received salaries in cash, The wise esteem him not a king who confines his attention to great matters only, although some impartial judges excuse a king that does so, because avaricious sycophants who Endeavour by cunning to obtain the position of the virtuous, often remind him of the difference of ranks, and succeed in lulling asleep such kings as are fond of external greatness, their only object being to make a trade of the revenues of the country, and to promote their own interests. But good princes make no difference between great and small matters; they take, with the assistance of God, the burden of this world and the responsibility of the world to come on the shoulder of resolution, and are yet free and independent, as is the case with the king of our time. In his wisdom, he makes himself acquainted with the successful working of every department, which, although former monarchs have thought it derogatory to their greatness, the first step towards the establishment of a good government. For every branch he has made proper regulations, and he sees in the performance of his duty a means of obtaining God's favor (Abu-L-Fazl, 1871:11).

Abul Fazl gave three classifications for the Mansabdars: first, those who had 500 and above Mansabs, second, those who had 400-200 Mansab, and third those who had 150-10 Mansabs (Abul Fazl, 1989: 250). This system gave rise to a community with various grades between the people and the ruler and a hierarchical system came into existence. Summing up in medieval times Indian society had a complicated system of rank and status on the basis of military power. The military power became a status symbol and the whole framework was designed around it, the Mughals also followed this pattern for peace in their kingdom and they did not try to change it (Mehta, 1996:151).

Land Revenue and Army Structure

Akbar's administration was a continuation of the Delhi Sultanate and so was his land revenue system.
Akbar's provinces were divided into Sarkars and Parganas. Each sarkar was divided into a number of parganas, for general administration there was a shiqdar and an Amil for assessment and collection of land revenue, there were many other posts as will like a treasure, a Qanongo and so on. There was a large army of people who were appointed to look after the matters of production i.e. the produce at the time of harvest and demanding the state's share of it. The land revenue system was the basis of the financial system of the state. Dahsala or a ten year system was the basis of Akbar's revenue policy. It was the logical evolution of the system of measurement adopted by Sher Shah which continued to operate in Hindustan i.e. the regions between modern day Lahore and Allahabad. On the basis of this system state demand was expressed as a cash rate based on local produce and local prices, the Dahsala did not means a ten years settlement but was on average of the production and prices of the last ten years. The productivity and local prices during the past ten years were worked out afresh on the basis of information and then averaged in cash, on the basis of this evaluation it is clear that the land revenue demanded was undoubtedly the heaviest demand, it put a lot of pressure on the peasants, this was the heaviest demand which the peasants had to meet under threat of severe action, including ejection and loss of life if he failed to meet it? (Chandra, 2007: 147-152).

The Dahsala system which was based on measurement or Zabt was introduced in many places like Lahore, Allahabad, Gujarat, Malwa, Bihar, and Multan, the second methods was crop sharing, there were many other methods in different areas for collection of revenue. All these methods needed a large number of intelligent, inspectors to check them.

Abul Fazl narrates that Akbar during his reign started a system of collection tax on individual basis, this system allowed the farmer to pay his tax based on his individual harvest. Only had to pay the tax on whatever produce he got. This system was different from the previous one found in the Mughal Empire, where a whole village had to pay the tax collectively, in this system every farmer had to pay the tax whatever he had a good produce or not because everyone had to share the tax equally. So when Akbar became ruler he changed this system, taking a step to reform the condition of the farmers. But this system in which a farmer could pay his tax according to what he produced or according to his financial condition did not prove to be beneficial for the farmer as the authority of collecting the tax was 
in the hands of the Zamindars or landlords and the ameer. They exploited the farmers and compelled them to pay the tax in conditions of droughts, floods or other natural calamities. Although Akbar had directly order them not to collect tax during natural calamities the Zamindars and landlords did not heed his advice.

Akbar took some preventative measures to stop this exploitation of farmers. He appointed a watch on the Zamindars to know who exploited and who did not. As a result of which he succeeded to some extent in returning the money to the farmers who had paid the tax under force. But despite all this he was not able to keep a watch over this whole kingdom, and this exploitation of the peasantry became common among the landlords, this practice continued in many parts of India in Akbar's reign. Akbar had a large and strong army for the smooth working of governance and administration. The Mughal army consisted of cavalry, infantry, artillery, elephant and camels, there was no easy way to assess the strength of Akbar's army. Troops were maintained by the Mansabdars according to their obligations denoted by their sawar rank, according to Montserrat writing in 1581, there were forty-five thousands cavalry, five thousand elephants and many thousands infantry paid directly from the royal treasury.

\section{Religious Views}

Abul Fazl was not a blind supporter of Islam, this was the reason that he respected the Hindu religion and supported the participation of Hindus in governance and administration. It can also be said that Abul Fazl was influenced by composite culture of his time, he argued that Hindus also believed in the theory of monotheism (one God) like Muslims but must Muslims get them wrong because they do not read their religious scriptures and so their criticism springs from ignorance (Abul Fazl, 1989:654). In fact Abul Fazl did not think that Islam was superior to all religious while Barani and other thinkers regarded it as supreme, this was the reason that many people called Abul Fazl a rebel, a Kefir, a Hindu or Agripujak etc ) Hassan, 1983:133). His religious thoughts were based on secularism which considered all religious equal and believed in religious fraternity and Sulh-i-Kul (peace everywhere) (Ali, 2006: 164).

He was considered an intellectual, a thinker who believed in the goodness of all religious. He liked rationality and innovations in every field, he did not like orthodox, traditional and customary values, and he said if traditions were sufficient for all the times then why the Prophet brought new thought. $\mathrm{He}$ argued that change in law and religious must be initiated with the passage of time. His modernity and religious rationality were reflected in the thoughts of Akbar who also declined to be a traditionalist himself and started innovative policies and customs in his reign, we can find its glimpse in Sulh-i-Kul and Deen-i-Ilahi. People from different religions and sects lived in India in the medieval age, it was not that easy to unite all of them under one umbrella. The Sultans of Delhi did not try to unite them during their reign and this was the reason that Delhi Sultanate was not as tolerant and liberal, for the most part, As Mughal period was. Akbar conducted many new experiments to please people of different religious groups, though he was not completely successful he did manage to unite them during his reign. Policies like Sulh-i-Kul and Din-i-Ilahi gave strength to his governance and administration but these new experiment were not as successful as Akbar hoped. Whenever the emperor's idea or practice happened to be inconsistent with the interpretation of Islam by the orthodox Ulema. That Akbar did not satisfy the requirement of sunny orthodoxy is clear enough. He did not look upon the Quran as the word of God, believe in revelation, and accept Mohammad as the last and greatest prophet. He had an inquiring mind for which orthodox Islam had no room at all. No true sixteenth- century Muslim could recognize the existence of truth in any religion than Islam. But Akbar felt that there was truth in every religion in an inscription composed by Abul- Fazl under the emperor's instruction for a temple in Kashmir occurs a significant sentence: each religious says, thou art one, without equal. Akbar was aware of the contradiction between this approach to religion and the orthodox Muslim point of view then he said: formerly I persecuted men into conformity with my faith and deem in Islam (Banerjee, 1986: 247-248).

\section{Conclusion}

Abul Fazl was Akbar's trusted courtier, he had a genuine adulation and reverence for Akbar, his firm belief in religious tolerance owed its origin to his formative years, when he and his family experienced the worst type of persecution at the hands of the orthodox Ulama. This proved to be the basis of a lasting friendship with Akbar, moreover, few could doubt that Akbar possessed the highest and noblest qualities of head and heart. No wonder that Abul Fazl found in Akbar the qualities of a king, philosopher and hero. Abul Fazl's official position as well as his personal views on religion and politics, required that he should defund, justify and extol Akbar and activities. Kings 
like Akbar and Ashuka had to fight a serious of battles at the start of their rule to consolidate their position and expand their empires. But when they achieved stability they proposed the ideas of peace, religion and friendship; be it the Dhamma of Ashuka or Sulh-i-Kul or Din-i-Ilahi of Akbar. Here some questions arise: why did Akbar need Sulh-i-Kul in his kingship? Wasn't he able to run his administration efficiently? Did he really need to introduce Din-i-Ilahi? Wasn't he successful in maintaining peace and order in his large empire? It was perhaps to make his subjects happy and to instil confidence in the other groups like Rajput and Marathas; he created the concept of Sulh-i-
Kul and Din-i-Ilahi. Abul Fazl rarely discussed the failures of Akbar or the short coming of his policies yet he was undoubtedly one of the greatest thinkers and scholars that India has produced. One may pick the tow theories are not logically compatible with each other. Indeed, he may be said to have tried to ride two horses, and combined (in anticipation) the view of Hobbes and James 1 (and he went much beyond James 1 in his claim for the sovereign). Yet the essential bedrock of rationality in Abul Fazl's thought commands respect, even admiration. Certainly no one after him in India debated the issues of sovereignty at the same high level of reason and abstraction.

\section{References}

Appodoroy A. (2002). Political Tough in India. Delhi: Khama Publication.

Abu-l-Fazl Akbarnama. (1989) Trans. H. Beveridge. Vol. I, II, III. Delhi: Low Price Publications.

Abu-1-Fazl the Ain-i- Akbari. (1871). Trans. H. Blochman. Ed. S.L. Goomer. Delhi: Naresh. C. Jain.

Ali Athar. (2006). Mughal India: studies in polity, society and culture. New Delhi: oxford university press.

Banerjee Chandra. (1986). Anil, new history of medieval India. S. Chand \& company ltd. New Delhi.

Bashir Ahmad (2009). Akbar the Great Mughal. Delhi, AAKAR Books.

Habib Irfan, Ed. (1997). Akbar and His India. New Delhi: Oxford University Press.

Mahajan V.D. (1997). History of medieval India. S. Chand \& company ltd. New Delhi.

Malleson G.B. (1899). Rulers of India: Akbar. Oxford.

Hassan Mohibbul. (1983). Historians of Medieval India New Delhi: Mecnakshi publication.

Mukhia Harbans. (2005). The Mughal of India. U.K.: Blackwell.

Richards John F. (2002). "The Mughal Empire” in the Magnificent Mughals, ed. Zeenut Ziad, 7 (Karachi, Pakistan: Oxford University Press.

Satish Chandra (2007). Medieval India: from Sultanate to the Mughals, Mughal Empire (1526-1748), part 2. New Delhi: Har Annand Publication.

Streusand Douglas E. (1989). The Formation of the Mughal Empire. New Delhi: Oxford University Press.

Sushma Yadav, Ram Avatar Sharma (2000). Bhartiya Rajya,Utpatti aevam Vikas, (Delhi: Aakar Publication.

V.R. Mehta (1996) Foundations of Indian Political Thought. New Delhi: Manohar. 


\title{
Najibullah Akbari ${ }^{\text {iD, Shirali Samimi* }}{ }^{*}$ \\ Bamiyan University, Afghanistan, Bamiyan \\ *e-mail: a.alisamimi.s7@gmail.com \\ A BRIEF HISTORY OF TELECOMMUNICATION AND TRANSMITTING INFORMATION IN AFGHANISTAN
}

\begin{abstract}
During the ancient time the important way for communicate between people was face to face and direct communications. Therefore all activities of communicate were limited with small community and they could not be aware from state of other countries and their neighbors of the direct methods. In the review of communications and the evolution between people were some progress from the beginning and expand connections of themselves through their various inventions. People did not have much ability to talk, interact and communicate with each other. But with the developing of different sciences and their integration with each other the possibility of human interaction has increased in modern era, nowadays we see their unlimited communication with each other that we are in the era of new technology, we have witnessing for the extensive communication of people that beings with each other that they can easily communicate everywhere of the world. In the present time all communication tools such as internet, mobile phone, satellite, cinema, television, radio are available for using of modern people, which they can communicate with each other and can see each other faces from every zone of the world. All these developments originate from the rich thinking and intelligence of humanity. In Afghanistan during the $20^{\text {th }}$ century after civil war the communication was also comfortable for using by supporting of subordinating countries via installing of modern technology.
\end{abstract}

Key words: communication, satellite, data, post office, stamp, massages and television.

$$
\begin{gathered}
\text { НаАжибулма Акбари, Ширали Самими* } \\
\text { Бамиян университеті, Ауғанстан, Бамиян қ. } \\
\text { *e-mail: a.alisamimi.s7@gmail.com }
\end{gathered}
$$

\section{Ауғанстандағы телекоммуникация}

мен ақпарат берудің қысқаша тарихы

Ежелгі уақытта адамдар арасындағы қарым-қатынастың маңызды тәсілі жеке және тікелей байланыс болды. Сондықтан барлық байланыс қызметі шағын қауымдастықпен шектелді және олар басқа елдердің Штаттарынан және олардың көршілерінен тікелей әдістер туралы біле алмады. Адамдар арасындағы байланыс пен эволюцияны шолуда басынан бастап біршама прогресс болды және олардың әртүрлі өнертабыстары арқылы өздерінің байланыстарын кеңейтті. ААамдар бір-бірімен сөйлесуге, өзара әрекеттесуге үлкен қабілетке ие болмады. Бірақ әртүрлі ғылымдардың дамуымен және олардың қазіргі дәуірде бір-бірімен интеграциялануымен аАамдардың өзара әрекеттесу мүмкіндігі артты, қазіргі уақытта біз олардың бір-бірімен шексіз байланысын, жаңа технологиялар дәуірінде екенімізді көріп отырмыз, біз бір-бірімен байланысатын адамдардың кең қарым-қатынасына куә болып отырмыз. Олар бүкіл әлемде оңай сөйлесе алады. Қазіргі уақытта интернет, ұялы телефон, спутниктік теледилар, кино, теледилар, радио сияқты барлық байланыс құра^дары қазіргі адамдар үшін қол жетімді, олар бір-бірімен сөйлесе алады және әлемнің кез келген нүктесінен бір-бірінің жүздерін көре алаАы. Барлық осы жетістіктер адамзаттың ақыл-парасаты мен ойлау жүйесінің жоғарылығынан туындайды. Азаматтық соғыстан кейінгі 20 ғасырда Ауғанстанда байланыс қазіргі заманғы технологияларды орнату арқылы бағынышты елдерді қолдай отырып қолдануға ыңғайлы болды.

Түйін сөздер: байланыс, спутник, деректер, пошта бөлімшесі, бренд және теледидар.

$$
\begin{gathered}
\text { НаАжибулма Акбари, Ширали Самими* } \\
\text { Бамианский университет, Афганистан, г. Бамиан, } \\
\text { * e-mail: a.alisamimi.s7@gmail.com } \\
\text { Краткая история телекоммуникаций } \\
\text { и передачи информации в Афганистане }
\end{gathered}
$$

В Аревности важным способом связи между ^юдьми бы^о мичное и прямое общение. Поэтому вся деятельность по общению ограничивалась небольшим сообществом, гАе они не могли быть осведомлены о иных прямых методах связи с соседними государствами. В обзоре 
коммуникаций и эволюции межАу АюАьми с самого начала был Аостигнут некоторый прогресс и расширились связи посреАством различных изобретений. У ююдей не было особых способностей разговаривать, взаимодействовать и общаться друг с Аругом на расстоянии. Но с развитием различных наук и их интеграцией друг с Аругом возможность человеческого взаимодействия увеличилась в современную эпоху, и в настоящее время мы не видим ограничений в общении Аруг с Аругом, так как мы живем в эпоху новых технологий. В настоящее время все средства связи, такие как Интернет, мобильный телефон, спутник, кино, телевидение, радио, доступны А^я использования современными АюАьми, которые могут общаться Аруг с Аругом, увидеть мица Аруг Аруга из мюбой точки мира. Все эти разработки происходят из богатого мышления и интемлекта человечества. В статье рассматривается история телекоммуникаций и передачи информации в Афганистане в XX-ом веке, после гражданской войны, когАа возникли различные виды связи за счет развития современных технологий.

Ключевые слова: связь, спутник, Аанные, почтовое отделение, марка и телевидение.

\section{Introduction}

Communication has been considered as one of the most important issues for human beings from the ancient time to present era, people have played the role communications in face to face, during the ancient times they conveyed their self's messages by using drums and smoke to others. On that time humans were unaware from the environment of their outside area at their small community, and they imagined the whole world in their limited zone and small society. Thus, people have acquired spoken through consistent and continuous efforts to more communicate with their surroundings in the long distance and used it to establish better and more effective communications. Although, humans entered the collection of oral or spoken with different dialect that began from ancient time In the wide range of spoken and thought were more attention to has been paid for the contents of messages, humans have used their five senses to communicate with each other, but the dominant sense has been the sense of hearing, which was more appropriate in linguistic communication between people than other senses. However, humans were also faced to many difficulties in transmitting their messages and desires within the field of spoken and needed more advancement means of communication, which led to a great invention in Greece, around 700 B.C and it was the invention of alphabet, which it acted as a bridge that connected speech and writing with each other. Due to closeness and proximity of these two phenomena, humans were able to think for transmitting their thoughts and sending them to others. Underlying of this historical turning point is evolution of three thousand years oral tradition and non-alphabetic communications that has been identified as the beginning of qualitative transformation of human communications (Castells, 1942). The spread of literacy did not occur until centuries after the invention and expansion of the printing and paper industry.

Johannes Gutenberg's invention of printing, enabled the people and humans to achieve written communication in addition to direct communication. With the beginning of this stage, humans entered to the era of writing or the period of Gutenberg. At the second half of the $15^{\text {th }}$ century, the printing industry rapidly developed, news and posts increased and it became possible to publish them, although this publication was not at one specific circle. The periodical press emerged in a half century and after the invention of the printing industry (Moyal, 1989). From the beginning of the $16^{\text {th }}$ century, news in Afghanistan and their neighbor country became a real commodity and print media became the first new means of communication. The completion of printing method with lead animated letters in the late $15^{\text {th }}$ and early $16^{\text {th }}$ centuries had a great impact on the spread of new ideas and the advancement of science and technology. With the invention, development and completion of the printing industry and creation of suitable conditions, a great transformation was started. In the field of preparation and reproduction of vast possible arose for dissemination of information and human thoughts and development of human culture and human civilization (Aronson, 1977). As the growing of the population and spread of them across the global, needs for information and exchange were increased. People and Humans who once used endurance runners fast horses and mail pigeons to send their messages, the press, publishers and newspapers failed to meet their basic need which was the rapid exchange of information for long times. The invention electricity and the advent of telegraph by "Samuel Morse" humans enabled to transmit information over long distances for the first time at high speeds through simple codes (Claisse, 2000). 
But the invention of telephone by Alexander Graham Bell and Thomas Watson was a great transformation in the field of transmitting information, making it possible for people and humans to communicate directly with each other's miles away and wirelessly (Bruce, 1973). Although this device had a great effect on increasing the speed of communication, but due to the use of wires, there were still limitation in communication. Humans were to build a device that could transmit information through space without the use of wire and at the speed of light, also cross all obstacles, until to the late nineteenth and early twentieth centuries, Guglielmo Marconi an Italian scientist built radio that spread news and information with surprising speed to distant places. The next step was the advent of television, which made events appear in the world as it happened. The spread of television after World War II and its aftermath made it a popular medium. In 1957, the Russians used Popovss idea to make a connection outside the earth and sent their first satellite called Sputnik into orbit. The first radio program of Afghanistan was broadcast in 1928 during the reign of king Amanullah Khan, but the national television of country was established in 1978 at the end of Dawood Khan >s rule, which made great development in the following years. Upon entering Kabul, the Taliban shut down all private and state media, keeping only the national radio and television station was active in Afghanistan, naming it Radio Shariat and broadcasting news through it. With the introduction of computer into human life and the creation of the Internet, a great change took place in human life and a great revolution called the information revolution took place. The spread of floods like the computer in recent decades has brought about the most significant change in the knowledge system, from the invention of printing in the fifteenth century or even from the invention of calligraphy onwards. Along with this extraordinary change, the expansion of networks and media whose job is to transfer knowledge and its constituent elements, namely data and information (GIPI-AF, 2006).

\section{Materials and methods}

The purpose of the current article are investigation for people of ancient time to the modern era, that at the first time communication was face to face and defectively, that all activities of political ambassador, cultural economy, merchant and trader were with the courier and they can't manage their order and transit of their commodity from one center of the countries to the other center and their customers. The main goal of this research is in Afghanistan especially in the $21^{\text {th }}$ century, we attempt to find some formal information and document of communication and telecommunication in Afghanistan by the supporter of this country that we gathered from books, articles and information of telecommunication and technology ministry of Afghanistan by some expert people that was educated in Pakistan, China, America and other neighbors countries and after 2001 when the civil war between Mujahidin and Taliban become finish, although peace came with new technology, the first network with name of Afghan wireless start its activation in 2002, after that other network like Roshan, Areeba now Mtn, Etisalat, Salaam and Afghan telecom activated in Afghanistan, between 20 - 50 percent people of Afghanistan have access to the communication and internet. All materials of this essay gathered by methods of analyses and resolution via system of library research.

\section{Results and discussion}

The History of communication and transmitting information

The background of communication and transmitting information is an important part of the extensive history of communication's science. The History is begins perhaps from the beginning of human's life; with use of smoke signals and drums. During the ancient times people and humans have attempted to move communication beyond the realm of earshot. In the early days, natives in African, American and parts of Asian used smoke signals and drums to establish relationship with each other's (Marvin, 1988). The history and advancement of communication which started from smoke signals and drums in the modern day new technology coming via internet, mobile and telephone systems has gone through many uprising and falling of it, it was invented and developed in many deferent times and deferent subsystems. Namely telegraph of semaphore system was built by "Claude Chappe" a French engineer weirdly in 1792 and it connect "Lille" and "Paris" cities by a line (Martin \& De Singly, 2000). As opposed to Chappe's system which involved pulleys rotating beams of wood, Edelcrantiz's system relied only upon shutters and was therefore faster. However semaphore as a communication system suffered from the need for skilled operators and expensive towers often at intervals of only ten to thirty kilometers (Du Boff, 1980). 
The first telecommunication system or semaphore systems which emerged in the 1790s in Europe. However, it was until the 1830s that electrical telecommunication system was created and started to appear (Swihart, 1995). The electrical communication, first conceived in the 1700 s and realized in 1832 by Charles Wheatstone, William Cooke and Samuel Morse, by invention of an electrical and engineering communication device, which later named telegraph, but there was mentioned in more resources, just from Mr. Morse, as inventor of telegraph. Through the next century, advancements in the telephone, radio, television and today's internet, completely changed the way people communicate and interact with each other (See J, 1979).

The word telegraph is derived from the Greek words tele, meaning "distance", and graphene, meaning "to write". It came into use toward the end of the $18^{\text {th }}$ century to describe an optical semaphore system developed in France (Hyde J, 1976). From the beginning of telegraphic systems, many of them have been used for transmitting information over centuries. The latest version of telegraph or electric telegraph which transmitted electric signals by means of a wired laid between stations, was developed in the early of $19^{\text {th }}$ century. When Alessandro Volta an Italian physicist invented the battery in 1800 , which reliably stored an electric current and allowed the current to be used in a controlled environment and after 20 years, Hans Christian Overstep a Danish physicist demonstrated the connection between electricity and magnetism by deflecting a magnetic needle, with experimenting with batteries and the principles of electromagnetism to develop electric telegraph that, for more than a hundred years was the principle means of transmitting information by wire or radio waves, although this successful system was basically limited to sending and receiving one message at once time (Du Boff, 1980).

This major limitation formed the context of, invention of the electric wire based telephone. According to Tom Farley, this system was invented at 10 March 1876 by Thomas Watson and Alexander Graham Bell, in Boston, Massachusetts, founded on electrical telegraph system (Moyal, 1989). It's a story when Bell and his colleagues were cooperating with Morse's group, to experimenting with electrical signals, on telegraph system to make acceptable that's related drawback and limitation, they achieved to a new device, which later named telephone. This electrical wire based telephone system was invented the 1870 s by Alexander Graham Bell, based on his earlier telegraph. When they began experimenting on Morse's electrical telegraph, for that's improvement and removing some related problems. Therefore, Bell's extensive knowledge of the nature of sound and understanding of music enabled him to consider the possibility of transmitting multiple messages at over the same wire and at the same time. Bell research had been progressed and he proceeded with his work on the multiple telegraph (Swihart, 1995). On the same time Hubbard and Thomas Watson, a young electrician were working on a device that would transmit speech electrically, but Bell didn't share his idea with them and secretly met with Joseph Henry the respected director of the Smithsonian institution, who listened to Bell's ideas for a telephone and offered encouraging words. Spurred on by Henry's positive opinion, Bell and Watson continued their work and experimenting (Myer, 1995).

By June 1875, the goal of creating a device that would transmit speech electrically was about to be realized. They had proven that different tones would change the strength of the electric current in a wire. To achieve success, therefore, they needed only build a working transmitter with a membrane capable of varying electronic currents and a receiver that would reproduce these variations in audible frequencies (Hyde J, 1976). On 2 June 1875, Watson was experimenting on telegraph, and discovered sound be transmitted over a wire completely by accidents of sound and wire ingredients which used for connecting, sending and receiving points. On that time Mr. Watson was trying to remove the accident causes, Bell recounted the critical moment in his journal and finally become success to invent his own device which he shouted into that, the following sentence: "Mr. Watson, come here, I want to see you" that had been heard and understood to next side. The first telephone call had just been made like that. Bell patent his device, Watson fashioned and designed that, this device quickly began to spread to other sites (Bell, 1971).

First mechanically automated telephone with a switchboard began to work in 1891 and used in smaller communications for decades or the turning of the century in major cities and countries. The first commercial telephone services were set up in 1878 and 1879 on both sides of the Atlantic in the cities of New Haven and London. The first telephone switchboard was placed in service of New Haven, Connecticut, in early 1878 , and demonstrated its greater efficiency over individual lines between each customer. The first use of telephone numbers and directories of telephone users appeared at about the same time (Aronson, 1977). The early development of the telephone was fraught with technical and financial 
problems, but were solved soon. The technology grew quickly from this point, with inter-city lines being built and telephone exchanges in every major city of the United States by the mid-1880s (Fischer, 1992).

By 1904 there were over three million phones in the US, still connected by manual switchboard exchanges. By 1914, the U.S. was the world leader in tele density and had more than twice the tele density of Sweden, New Zealand, Switzerland, and Norway. The relatively good performance of the U.S. occurred despite competing telephone networks not interconnecting. For the next half-century, the network behind the telephone grew progressively larger and much more efficient, and after the rotary dial was added itself instrument changed little until touch-tone signaling started with replacing of the rotary dial in the 1960s (Claisse, 2000).

Within the hundred years and developing of this phenomenon, finally, in the mid - 1960s, the Scottish mathematician James Clerk Maxwell produced a pair of equations whose solution predicted electromagnetic waves propagating at the speed of light. It took 20 years to verify this prediction in the laboratory, and another 20 years for the first "mobile" application to take place early mobile telephone systems resembled at broadcast systems, in that powerful transmitters were used to cover a distance of 20-30 miles from a high tower or rooftop. The reuse of any channel for a different call required separations of more than 50 miles (Larry, 1999). After the 1960s, mobile systems evolved over time until they took on their present form.

We now take for granted that we can call anyone, anytime and anywhere, and have moved on to ask whether such a call would be safe while driving, or socially accepted in public places. The technology arena has also moved on from voice to wireless information. Yet the entire history of communication and especially mobile radio is barely so many years old.

\section{History of Communication in Afghanistan}

The Islamic Republic of Afghanistan is located in south western Asia and encompasses approximately 652,000 square kilometers. It is a landlocked plateau between Iran and Pakistan that also shares borders with China, Tajikistan, Turkmenistan, and Uzbekistan. The high mountains which are part of the Hindu Kush system, cover much of the country and small glaciers and year-round and also the snowfields are common in some part of the country. Afghanistan is one of the world's poorest and least developed nations, behalf of that the communication is also unreachable for knowledge of
Afghans society. During the civil war in Afghanistan the roads, power, water, telecommunications, healthcare, and education have been disrupted or dysfunctional. One in five children dies before the age of 5, mostly of preventable diseases. Life expectancy is about 42 years for males and 43 for females. The literacy rate is 36 percent in urban areas (51 percent for males and 21 percent for females) and even lower in rural areas. Afghan society during civil war don't have access to modern technology and have much more problem, so the 32 percent of the children are in school, but only 3 percent of girls attend school, in some province such as Bamyan the percentage of girl student is higher than boy's student and in some province like south Afghanistan percentage of girl school is zero. Many schools for girls have been burned, and teachers and families of the girls that attend to school have been threatened or even murdered by insurgents (Wentz \& Kramer, 2008). Until recently, the country lacked a functioning government as well as laws, regulations, and enforcement mechanisms. Poverty and unemployment remain widespread; currently about 40 percent of the population is unemployed. The lack of skilled workers and administrators is also a pressing problem for labor. The Afghan economy largely depends on growing poppies and producing illicit drugs. Ninety percent of the world's opium is derived from Afghanistan, which has raised concerns that the country is in danger of becoming a full-fledged Nation-state. A growing insurgency is fueled by the booming drug economy (Ibid).

Administratively, Afghanistan is divided into 34 provinces and some province right now in the era of internet and computer don't have access to the communication like Pamir and Wakhan in northeastern zone of Afghanistan, this country also divided into 365 districts. Kabul is the capital of Afghanistan and located in central of Afghanistan at an elevation of about 5,900 feet. The major economic centers are Kabul, Herat, Kandahar, Jalalabad, Khost, Mazar-eSharif, and Kunduz. The population of the country is around 35 million (NISPAA, 2011).

Telecommunication industry include TV, telephone, telegraph, Internet, fax, telex printer and so on. Transmission and acquisition devices include satellite, cable, receivers that operate on both $\log$ and digital input systems. Telecommunication equipment is much cheaper by cable, For example, two telephones or a computer or other cable electronic devices can talk for hours because the transmitting and receiving devices are in the devices themselves, but when talking by a mobile phone, 
there is need for a satellite tower antenna and is very expensive (Ministry of Communications, 2003). In Afghanistan, 96 percent of telephone communications are by satellite. Which is the largest consumer income and capital flight. In today's world information is exchanged by cable systems, at stable locations such as homes and offices and at unstable locations, by mobile and satellite devices. Unlike, in Afghanistan, the landline telephones have remained stable and mobile telecommunications systems have developed (Wentz \& Kramer, 2008).

Afghanistan took a steps in the world of electronic communications by installing a cordless telephone in 1898 at the Citadel in Kabul. The Ministry of Communications was established in Afghanistan In 1955. The small telephone system with a capacity of 25 lines was installed at the north of the citadel. Telegraphic services were another type of telecommunication facility that was established in 1914 in Afghanistan (Government of Afghanistan, 2010). The telegraph system with twokilowatt power was installed primarily for military purposes in the Babur Garden. In 1919, several telephone systems (switchboards) with 50-lines and 100-lines, were installed the Post office in Shah-EDo-Shamshirah (King of Two Swords). In the same year, 14 students were awarded scholarships to study wireless telegraphy abroad for the first time. In 1920, another British-made telegraph machine that was installed in Kabul, which was used until 1932 (Ibid).

Afghanistan became a member of the International Telegraph Union (ITU) in April 1928. (The name of International Telegraph Union was formed in 1865 and in 1932 its name was changed to the International Telecommunication Union). In 1930, seven telephone device stands and shortwave telegraphs were purchased from Marconi an Italian company, they installed and assembled in Kabul, Herat, Mazar-e-Sharif, Maimane and Khost (Baharustani, 2013). In late 1933, another system with a higher power antenna was purchased from the same company, installed and assembled at the Telegraph Central Repair in Kabul. In 1949 a stand of an automatic relay telephone with a capacity of 1300 lines was purchased from Bell Company and its cable network was completed in 1950. In 1953, another telephone device stand with a capacity of 5000 lines that was provided by Siemens Company, and after the completion of its network, launched in 1957. By providing of ancillary equipment from Siemens Company, the Ministry of Communications established telephone exchanges between Kabul and Mazar-e-Sharif and between Kabul and Kanda- har in 1959 (Ibid). In 1961, a 1500-line device was purchased from Czechoslovakia and installed in Kabul. In the same year, a connection was established between Kabul and Kandahar. Kabul was also connected to Torkham commercial port, the northern part of country. At the same time, telecommunication services were provided using three-channel and 12-channel systems with a length of approximately $14,000 \mathrm{~km}$ of cable network throughout the country (Ibid).

International communications and transmitting information between some neighboring countries such as Pakistan, Iran and Turkey were conducted through Afghanistan. The total number of channels at that time was more than 120. Due to the growing demand for telephone services, a network development plan was launched in Kabul in 1964 (Poopal, 2008). According to that plan, 3,000 telephone lines were developed in Shirshah Mina, 3,000 telephone lines in new city of Kabul, 200 telephone lines in Pul-e-Charkhi and 5,000 telephone lines in the central area of Kabul. This network completely started its activities in 1969 (Ibid).

A 20-kilowatt radio transceiver station was installed in Kabul which connected Kabul with Paris via Radio waves. In late 1964, a ten-kilowatt radio transmitter and two receiver stations were provided by a Phelps company (Netherlands) and was used to provide communication with information transit centers in Paris, New Delhi, London and Moscow. In 1973, the Development Network project (the second telecommunication project) was set upped in Kabul with the technical advice of the International Telecommunication Union (Baharustani, 2013). By implementation of the third project, urban subautomatic devices were installed in new city Kabul, Khair Khaneh and Makroryan. Procurement of network equipment through Siemens Company had activated 13,200 telephone lines in Kabul. Afghanistan became a member of the Asia-Pacific Telecommunication Association (APTA) during the year of 1979. In the mid-1970 foundation of telecommunications services, including telephone and telegraph, were available, at the districts level in Afghanistan. Although the telecommunications system was mostly limited to some parts of the government, and common people also had a little access to services. Unfortunately, from the year of 1980 to 2000 , there were completely destroyed all the country's infrastructures and wealth, including the telecommunication systems. In the most parts of country, even essential telecommunication services were not available (Government of Afghanistan, 2010). 
After 2001, the Ministry of Telecommunications and Information Technology was one of the first departments in Afghanistan to developed general strategies and policies for the telecommunications sector to enable companies and private departments for investing and operating in the field of telecommunications. Since that time the companies of Afghan Wireless, Roshan, MTN Group, Etisalat, and Telecom network have been active, and nowadays almost 80 percent of this country is covered by telecommunication networks (Poopal, 2008).

The Telecommunication Institute has been established recently within the Ministry of Telecommunications, which educates students at the bachelor's level. There are currently 40,000 students working and educating in telecommunications. There are currently more than 76.3 thousand landline telephones operating across the country. And so far, $\$ 1.5$ billion has been invested by foreign countries in Afghanistan in the field of telecommunications. About $10 \%$ of the country's population (more than three millions) use Internet services, while in neighboring countries, this figure is 40 percent (Ibid).

Mobile phones which first made in 1983 , by a man named Martin Cooper, were used only by merchants until 1991, and after 1992, the use of this device become public. The first model of a modern contemporary mobile phone was produced in2002, which the first being them Sony Ericsson T68i mobile phone. Then, in 2010 today's smartphones were introduced, which now play a very important role in human life, and not only use for communication, but also use in many aspects of life, and it has had a great impact on human life.

\section{Conclusion}

As we know that the humans are the bomblets creature in the livelihood of environmental studies by many reason that they are very curious and exploration for communicate with other society in the world, the relationship between the tribe, merchant, bourgeois and the nobles are connected from east to west and north to south by the knowledge and intellectual way to find successfully achievement. History of communication between society sometime have risen and sometime fallen by the method of people gathering and communicate during different period with the history event from the ancient time to now had some terminology and Significance for the next generation, but in Afghanistan there is no experience for the communication because of the civil war and there is no information for using of them. Although we find some sources till the year of 1918 in Afghanistan communication overshow via post office and the inauguration of communication related to the reign of Amir Amanullah khan in the year of 1919. The statistic bases of that in Afghanistan at the decade of 1970 estimated 28000 line of telephone was active in Afghanistan. After one decade it increased to 31000 line of telephone and more of them was settled in Kabul, political capital of Afghanistan. During the civil war in Afghanistan all base and foundation of technology was ruined, also the people had traveled to Pakistan, Iran and other countries. After the fallen of Taliban regime and the supporting of foreign countries the extension of communication starting again with new system such as mobile, phones and internet.

\section{References}

Afghanistan Ministry of Communications (2003), Telecommunications and internet policy. Kabul. www.moc.gov.af and www. trb.gov.af

Aronson, Sidney (1977). Bell's Electrical Toy. What's the Use?' The Sociology of Early Telephone Usage, in de sola Pool, I. (Ed.) The Social Impact of the Telephone. Cambridge: MIT Press, pp. 300-10.

Baharustani, Rahima. (2013) "Study of Afghan Telecom Industry". [Online]. Available: http://www.aisa.org.af/content/media/ documents/study_of_afghan_telecom71120241744332131553325325.pdf[Accessed: 29 Apr. 2017].

Bell, (1971). High-Capacity Mobile telephone System Technical Report, Prepared by Bell Laboratories, included within FCC Docket 18262

Bruce Robert R. (1973). Alexander Graham Bell and the Conquest of Solitude, Boston 1973 37, 121

Castells Manuel (1942). The rise of the network society, Hasan Chawoshian, 1380

Claisse Gerard (2000). Identités Masculines et Féminines au Telephone. Des Rôles, des Pratiques des Perception Contrastés. Réseaux 18, no.103, pp.51-90

Du Boff R. B. (1980). Business demand and the development of the telegraph in the United States, 1844-1860. Business History Review, 54(04): 459-479.

Fischer Claude (1992). America Calling. A Social History of the Telephone to 1940. Berkley: University of California Press.

GIPI-AF (2006). Assessment Report. State of Telecommunications and Internet in Afghansitan. Internews Europe. January 2012 http://www.enternews.eu/news/gipi-afghanistab. 
Government of the Islamic Republic of Afghanistan (2010). Telecommunication in Afghanistan, Kabul Process. "Kabul Process". February 2012 http://www.kabulprocess.gov.af/.

Haddon Leslie (2004). Information and Communication Technologies in Everyday Life: A Concise Introduction and Research Guide. Oxford: Berg.

Hyde J. Edward (1976). The Phone Book: what The Telephone company would rather you not know, Henry Regenry Company, Chicago. 30 .

Larry Greenstein (1999). 100 Years of Radio, Speech at WINLAB Marconi Day Commemoration, Red Bank, NJ, September

Martin, O. and De Singly, F (2000). ‘L`Évasion Amicable. L〉Usage du Téléphone Familial par les Adolescents’, Réseaux 18, no.103: pp. 91-118.

Marvin Caroline (1988). When Old Technologies were New: Thinking about Communications in the Late Nineteenth Century. Oxford: Oxford University Press.

Moyal Ann (1989). The Feminine Culture of the Telephone. People, Patterns and Policy. Prometheus 7, no.1: pp. 5-31.

Myer Ralph .O (1995). Old Time Telephones!: Technology, Restoration and Repair, Tab Books, New York. 123 Excellent.

NISPAA (December 2011). ICT Collaboration Conference, "Presentation by NISPAA Representative", Kabul, 11- 12. Presentation.

Poopal Karim (February 2008). Information and Communication Technology Strategy «ICTS», Information and Communication Sector in Afghanistan. December 2011.

See J. L. Heilbron (1979). For a discussion of electrical science before the discovery of the battery, Electricity in the 17 th and 18th Centuries: A Study of Early Modern Physics (Berkeley: University of California Press).

Swihart Stanley (1995). Independents Show Bell the Way to Big-City Dial Service, Telecom History Issue 2 Spring, p94.

Wentz Larry, Kramer Frank, Starr Stuart (2008). Information and Communication Technologies for Reconstruction and Development. Afghanistan challenges and Opportunities, Center for Technology and National Security Policy, National Defense University, USA. 